allein durch die individuellen Unterschiede der Enzymaktivitäten geklärt werden, da z. B. im Falle der Benzoylcholinhydrolyse durch Vollserum (Abb. 7) der Fehler mit TRIS-Essigsäure $\pm 10 \%$ beträgt, während er mit anderen Puffern ein Mehrfaches davon ausmacht. Ähnlich sind die Verhältnisse z. B. bei der endogenen Lipoproteinlipase (Abb. 3). Auch hier beträgt der Fehler beim TRIS-Essigsäurepuffer $\pm 10 \%$; derselbe Wert wurde bei verminderter Absoluthöhe mit Veronalpuffer gefunden, während der Fehler mit CitronensäurePhosphatpuffer $20 \%$ beträgt.

Damit ist erwiesen, daß sowohl die Absoluthöhe der Enzymaktivität als auch die Fehlerbreite der jeweiligen
Bestimmungsmethode von der chemischen Zusammensetzung des Puffers abbängt, sofern nicht mit Reinfermenten gearbeitet wird. Es wäre daher wünschenswert, daß bei Beschreibungen von Enzymen und der Bekanntgabe von Methoden der enzymatischen Analyse, größeres Augenmerk auf die chemische Zusammensetzung der Puffer gelegt würde, als dies bisher der Fall war. Speziell für die klinische Chemie ist $z u$ fordern, daß bei allen Methoden außer $\mathrm{pH}$-Wert und Ionenstärke auch die genaue chemische Zusammensetzung des verwendeten Puffers sowie die Fehlergrenze der Methode bei den gewählten Bedingungen anzugeben ist.

\title{
Literatur
}

1. PrLz, W., Hoppe-Seyler's Z. physiol. Chem. 345, 80 (1966). 2. Pizz, W. und I. JohanN, Hoppe-Seyler's Z. physiol. Chem., im Druck. - 3. Pilz, W., H. Hörlein und E. StelzL, Hoppe-Seyler's Z. physiol. Chem. 345, 65 (1966). - 4. Przz, W., I. JohanN und E. Stelzl, Z. analyt. Chem. 215, 260 (1966). - 5. Pilz, W., diese Z.3, 89 (1965). - 6. Eucken, A. und E. WICKE, Grundriß der physikalischen Chemie, S. 547, Verlag Geest u. Portig, Leipzig (1958). - 7. Hörleis, H. und W. PILZ, Hoppe-Seyler's Z. physiol. Chem. 327, 256 (1962). - 8. Prlz, W. und I. Johann, Z. analyt. Chem. 218, 426 (1966). - 9. PrIz, W., Hoppe-Seyler's Z. physiol. Chem. 328, 1 (1962). - 10. PrLz, W., Hoppe-Seyler's Z. physiol. Chem. 328, 247 (1962). - 11. PrLz, W., Mikrochim. Acta (Wien) 1961, S. 614. - 12. Pilz, W. und I. JohanN, Z. analyt. Chem. 212, 410 (1965). - 13. Pilz, W., Methoden der Enzymatischen Analyse, S. 765, Verlag Chemie GmbH, Weinheim/Bergstr. (1962). - 14. Prlz, W. und H. Hördern, Hoppe-Seyler's Z. physiol. Chem. 339, 157 (1964). - 15. PiLz, W., Zschr. exper. Med. 132, 310 (1959). - 16. Priz, W. und İ. JohanN, Z. analyt. Chem. 210, 113 (1965). - 17. Przz, W. und H. HöRLEIN, Hoppe-Seyler's Z. physiol. Chem. 330, 212 (1963). - 18. Pilz, W. und I. Johann, Z. analyt. Chem. 215, 105 (1965).
Dr. W. Pilz

Physiol.-chem. u. analyt. Labor der ärztl. Abteilung

559 Leverkusen-Bayerwerk

\section{Fractionation and determination of 17 -ketosteroids by means of column and thin layer chromatography}

\author{
By L. E. Böttiger and B. P. LisBoA \\ From King Gustaf Vth Research Institute, (Head: G. Birke, MD), Stockholm, Siveden
}

(Eingegangen am 2. August 1966)

\begin{abstract}
A method is described for the fractionation of urinary 17-ketosteroids by use of gradient elution chromatography on aluminium oxide followed by one-dimensional multiple thin layer chromatography on silica gel G.

Androsterone, etiocholanolone, $11 \beta$-hydroxy-androsterone, 11-oxoetiocholanolone, 11 $\beta$-hydroxyetiocholanonole, 11-oxo-androsterone and a fraction containing dehydroepiandrosterone together with its rearranged product, $i$-androstanolone, were determined by means of the ZiMMERMANN reaction. The individual steroids were characterized by means of one- and two-dimensional thin layer chromatography using single and multiple runs, and by several "in situ" developed colour reactions. The method has been developed for sulphuric acid hydrolysis followed by continuous ether extraction as well as for enzymatichydrolysis; the results with the different hydrolysis procedures have been discussed. Results are presented for the fractionation of fifteen normal urines after sulphuric acid hydrolysis. The ratio between the amounts of etiocholanolone and androsterone obtained by this method has been compared with that found after additional oxidation of their $\Delta^{9}\left({ }^{11}\right)$ dehydro-derivatives.
\end{abstract}

Es wird eine Methode zur Fraktionierung der 17-Ketosteroide des Harnes durch Gradienten-Elutions-Chromatographie an Aluminiumoxyd mit anschließender mehrfacher eindimensionaler Dünnschichtchromatographie auf Silikagel G beschrieben. Mittels ZimmermanNReaktion wurden folgende Substanzen bestimmt: Androsteron, Ätiocholanolon, 11 $\beta$-Hydroxyandrosteron, 11-Oxyätiocholanolon, 11 $\beta$ Hydroxyäthiocholanolon, 11-Oxyandrosteron und eine Fraktion enthaltend Dehydroepiandrosteron zusammen mit seinem Umwandlungsprodukt i-Androstanolon. Die einzelnen Steroide wurden charakterisiert durch ein- und zweidimensionale Dünnschichtchromatographie - und zwar einfach und mehrfach - und durch einige „in situ“ entwickelte Farbreaktionen. - Die Methode wurde sowohl für schwefelsaure Hydrolyse mit kontinuierlicher Äther-Extraktion wie auch für enzymatische Hydrolyse entwickelt. Die Ergebnisse mit den verschiedenen Hydrolyse-Verfahren werden diskutiert. Es werden die Ergebnisse der Fraktionierung von 15 Normalharnen nach Schwefelsäure-Hydrolyse mitgeteilt. Das nach dieser Methode ermittelte Verhältnis Ätiocholanolon/Androsteron wird mit demjenigen verglichen, das nach zusätzlicher Oxydation ihrer $\Delta^{9}\left({ }^{12}\right)$-Dehydro-Derivate gefunden wird. 
As the urinary $17-$ ketosteroids (17-KS) have different origins, a knowledge of the elimination of each metabolite and the ratio between some of them is necessary for a clinical investigation of the gonadal and adrenal functions. - The first fractionation procedure of Dingemanse et al. (1), may be followed by methods using different hydrolysis and separation procedures; some of these use complicated techniques, are time consuming and expensive, or give only a partial separation of the most important 17-ketosteroids. Thinlayer chromatography techniques provide an adequate separation of closely related 17-ketosteroids, with high reproducibility and recovery. $(2,3,4)$. The present work we investigate the possibility of combining column adsorption chromatography with gradient elution and a multiple one-dimensional thin-layer chromatography, in order to give complete separation of the principal six urinary ketosteroids, and thus make possible the study of the individual values and their ratios. As acid hydrolysis, in spite of some inconveniencies, is the most widely employed hydrolysis procedure, sulphuric acid was used for the hydrolysis of the steroid conjugates. For comparison, studies with enzymatic preparations were also performed.

\section{Methods}

\section{Collection of urine}

$24 \mathrm{hrs}$. urine specimens were obtained from 8 men and 8 women of various age, hospitalized for various benign conditions, all with normal liver function and without signs or symptoms of endocrine disorders. The urines were examined in a fresh condition without the use of preservatives, in 24 hour collections.

\section{Hydrolysis}

Most of the urines were submitted to acid hydrolysis using 1/10 (v/v) of $40 \%$ sulphuric acid, extracted with ether continously for 16 hours, and purified as described by Plantin and Birke (5). In two cases, aliquots were submitted torenzymatic hydrolysis using a Helix pomatia preparation (L'Industrie Biologique Francaise S. A., Gennevilliers/Seine, France): $250 \mathrm{~m} l$ of urine were diluted to $500 \mathrm{ml}$ with water, adjusted to $\mathrm{pH} 5.2$ with acetate buffer (end of molarity: $0.02 \mathrm{M}$ ) and submitted to hydrolysis with 8.000 units sulphatase (RoY) and 1.000 units $\beta$-glucuronidase (FIsHMaN) $/ \mathrm{m} l$ for 48 hours at $+37^{\circ}$. The hydrolyzed steroids were extracted and purified as described above.

\section{Ketone separation}

After hydrolysis the extracts were treated with Girard's reagent T (6), and determination of total 17-KS was performed on an aliquot of the ketonic fraction.

\section{Total 17-KS-determination}

It was performed using the ZIMMERManN reaction with stabilized alcoholic potassium hydroxide, according to Hamburger (7). The corrections of AlLEN (8) and of Gibson and EvelyN (9) were employed on total determinations, but the corrected values differ only slightly from uncorrected values after column chromatography, indicating that the eluted fractions are pure.

\section{Column chromatography}

It has been performed with a linear gradient on aluminium oxide (alumina) with a column according to ZYGMunTowicz et al. (10); for particulars, see PlaniIn and Birke (5). The gradient concentration was obtained by using four identical cylinders situated on the same level, connected - just above the bottoms - by semicapillary tubes with valves (Fig. 1). The first cylinder (a) contains

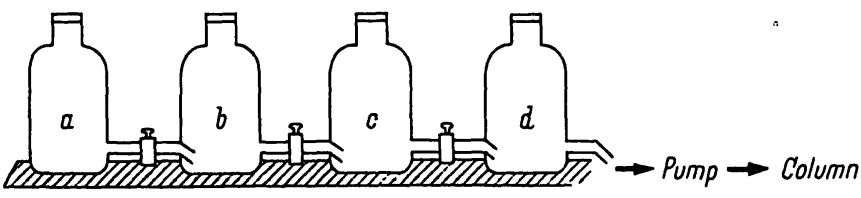

Fig. 1

Apparatus utilized for gradient elution chromatography The bottles contain the same volume of solvent: benzene (b) and (d) $0.2 \%$ methancl in benzene (c) and $2 \%$ methanol in berizene (a)

$2 \%$ and the third $0.2 \%$ methanol in benzene, the second and the fourth only benzene. For the theoretical basis of the linear gradient, SCe LEBRETON (11).

The eluates were collected with a 50 tube fraction collector, $5 \mathrm{ml}$ in each tube. Total 17-KS determination was performed on an aliquot (2/5) from each tube. The rest of the samples were pooled in four frations, consisting generally of the contents of the following tubes:

$$
\begin{aligned}
& \text { I: tubes } 1-15 \\
& \text { II: tubes } 16-28 \\
& \text { III: tubes } 29-41 \\
& \text { IV: tubes } 42-50 .
\end{aligned}
$$

In each case, the exact number of tubes belonging to each fraction was decided from the position of the peaks in the curve obtained with the column chromatography. The number of tubes in each fraction may vary slightly from one sample to another, depending upon variations in the alumina activity.

\section{Thin layer cbromatography (TLC)}

It has been used both for the characterisation of the steroids found in the different peaks and for the further sepa:ation of fractions III and IV. In this study, one-dimensional and two-dimensional TLC on silica gel $G$ was performed according to the experimental conditions described by LISBOA $(12,13,14)$. For complete separation of the steroids in fractions III and IV multiple developments were also employed.

The following solvent systems were used:

$\begin{array}{ll}\text { Cyclohexane/ethylacetate } & 50: 50 \text { (System C) } \\ \text { Chloroform/ethanol } & 95: 5 \text { (System L) } \\ \text { Benzene/ethanol } & 49: 1 \text { (System P) } \\ \text { n-hexane/ethylacetate } & 75: 25 \text { (System 0) } \\ \text { Cyclohexane/ethylacetate } & 40: 60\end{array}$

For quantitative determinations, aliquots of fractions III and IV were carefully put on the plates in a row, $2.5 \mathrm{~cm}$ above the lower edge, using a Pasteur pipette and without damaging the silica gel layer (Fig. 2). On the both sides of the test extracts, standard mixtures of the steroids to be analysed were added. After chromatography the central area containing the urinary extracts was protected by a glass plate, and the standards on both sides of the chromatoplate were developed by means of anisaldehyde/sulphuric acid reagent (15). Thereafter, the silica gel areas situated between the standards (shaded areas in the fig. 2) were carefully scraped from the plates and transferred to special columns (diameter $10 \mathrm{~mm}$, length $5 \mathrm{~cm}$ ) with coarse sintered glass disks in the bottom, similar to those used for pregnandiol determinations (16). The preparation of the column was done in the following way: one layer of washed quartz, one layer of silica gel, the silica gel from the chromatoplate and finally quartz again. The steroids were eluted with $3 \times 5 \mathrm{~m} /$ of ethanol. The eluates, after evaporation, were submitted dircctly to the ZimmermanN reaction.

Separation of $\Delta^{9}\left(^{(1)}\right.$ debydroandrosterone and $\Delta^{9}\left({ }^{11}\right)$-delyydroetiocbolanolone Aliquots of the samples containing a mixture of the four steroids (fraction III) were submitted to treatment with osmium oxide and sodium permanganate, respectively; in both cases $\Delta^{9}\left({ }^{11}\right)$-compounds give dihydroxy-derivatives, which easily may be separated from the corresponding saturated compounds by means of TL.C. 


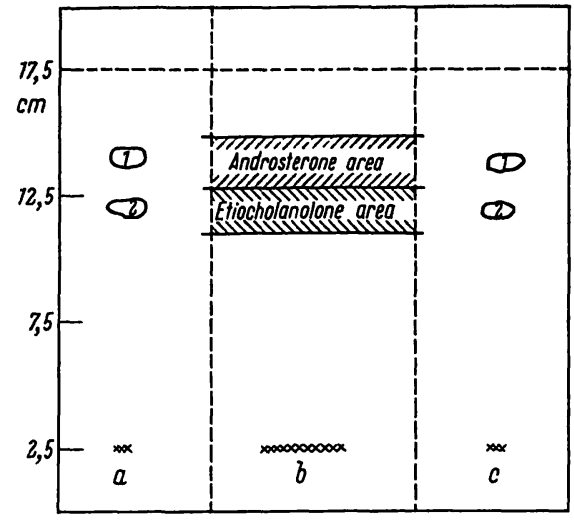

Fig. 2

One-dimensional multiple chromatography of aliquots of eluentfraction III on silica gel G (3 developments), using solvent system $C$ (ethylacetate/cyclohexane $50: 50$ )

The eluate of the urinary extract is deposited on the central starting line (b), a mixture of androsterone and etiocholanolone standards $(1: 2)$ is deposited on each side at the same starting line (a). After development of the plate, the areas containing the standards are stained (the central area with the test sample is covered during the staining procedure) by using the anisaldehyde/sulphuric acid reaction

\section{Treatment with osmium-L'I-oxide (17)}

Two-three drops of pyridine and $3 \mathrm{ml}$ of a $0.5 \%$ ether solution of osmium-VI-oxide was added to an aliquot of the steroid sample, dissolved in $2 \mathrm{ml}$ of ether. The tube is then sealed in a $\mathrm{N}_{2}$-atmosphere and left at room temperature for 7 days. The mixture is then saturated with hydrogen sulphide and filtered over glass filter. Each sample is deposited on the starting line of a chromatoplate, which is submitted to a three times repeated one-dimensional TLC, using solvent system $C$. The regions containing androsterone and etiocholanolone are eluted as described above and the ratio between them was determined after the ZIMMERManN reaction had been performed.

Treatment with sodium permanganate (18)

The hydroxylation with permanganate is carried out by a modification to micro scale of the method employed by SAVARY and DESNUELLE (18) for the hydroxylation of unsaturated fatty acids. An amount of steroids (50-100 micrograms), dissolved in cold acetone is treated by a few drops of a $0.15 \%$ sodium permanganate solution in aqueous $0.1 \%$ potassium hydroxide solution. The mixture is shaken and after 5 minutes a few drops of a saturated aqueous sodium bisulphite solution is added until the permanganate colour disappears. The solution is then extracted three times with ethylacetate; the three organic extracts are pooled, evaporated and submitted to TLC for the separation of androsterone and etiocholanolone as described above. - In order to investigate the possibilites of adapting this method for quantitative determinations, aliquots of standards containing 50 micrograms of androsterone and etiocholanolone, respectively, were submitted to the same procedure for the calculation of the recovery.

\section{Reliability of the method}

The reliability of the method employed has been tested with regard to specificity, recovery and reproducibility.

Specificity: To investigate the specificity of the gradient elution chromatography under the conditions employed in this study, experiments have been carried out with the following standards: androstane-3,17-dione, etiocholane-3,17-dione, dehydroepiandrosterone, iso-androsterone, iso-etiocholanolone, androsterone, etiocholanolone, $11 \beta$-hydroxyandrosterone, $11 \beta$-hydroxyetiocholanolone and 11-oxo-etiocholanolone. Futhermore, the eluates of the four fractions obtained from pooled normal urines after gradient elution chromatography were further submitted to fractionation using TLC. The different steroids were characterized by their chromatographic mobilities an silica-gel layers and by colour reactions, such as the anisaldehyde/sulphuric acid- and the ZIMMERMANN reactions, developed "in situ" $(2,15)$.
Recovery: The recovery of the method depends upon those of both chromatographic techniques. The recovery of $17-\mathrm{KS}$ after gradient column chromatography has been studied previously for free steroids $(19,20)$ and is higher than $95 \%$. Using TLC the tecovery varies from 86 to 94 (mean 89.2) \% for the different $17-\mathrm{KS}$ investigated here. The calculation of the absolute quantities of the steroids of the eluated fractions III and IV according to their relative values in the corresponding fractions makes it unnecessary to correct for losses during the thin-layer chromatography procedure. - The recovery has also been studied after treatment of the steroids of fraction III with sodium permanganate under alkaline conditions. The results obtained with 5 aliquots containing androsterone and etiocholanolone (50 microgram eacb) give a recovery of 87.8 (range $80.9-96.5$ ) \%, measured as dehydroepiandrosterone.

Reproducibility: As for the recovery, the reproducibility depends on those of the two chromatographic procedures used. The coefficient of variation of the results obtained after gradient elution chromatography of $17-\mathrm{KS}$ has been shown to be in the order of $6 \%(5,20)$. The reproducibility of TLC depends upon sufficient resolution of steroids with close polarity and of the reproducibility of their $R_{\mathrm{F}}$-values; both are possible to obtain under the standardized conditions which have been used. The values used for the calculation of the ratio E/A were averages of two determinations for both androsterone $(A)$ and etiocholanolone $(E)$, in order to avoid errors resulting from elution procedures.

\section{Results}

\section{Qualitative analysis of the four fractions}

Experiments carried out with known standards, investigation of the four eluate fractions by means of thinlayer chromatography, and colour reactions developed "in situ" have shown the following composition of the eluates.

Fraction I: Using solvent systems $\mathrm{C}, \mathrm{O}$ and $\mathrm{P}$ it was possible to detect androstan-17-one, androstane-3,17dione and etiocholane-3,17-dione. However, most of the material in this fraction remained unidentified and probably consists of artefacts of hydrolysis. Gradient elution chromatography of androstane-3,17-dione and etiocholane-3,17-dione standards show that these two steroids are completely eluted in this fraction.

Fraction II: All the dehydroepiandrosterone, iso-androsterone and iso-etiocholanolone submitted to gradient elution chromatography have been recovered in this fraction. TLC of this fraction, obtained from pooled extracts from normal urines, has shown that a great part of the ZIMMERMANN chromogens contained in this eluate was no longer dehydroepiandrosterone but a less polar steroid. This steroid was also obtained when dehydroepiandrosterone standard was submitted to the same hydrolysis procedure. This suggests that this steroid was $i$-androstan-6-ol-17-one, resulting from rearrangement of dehydroepiandrosterone. This eluate fraction includes all the so-called $\beta$-ketosteroids-dehydroepiandrosterone, iso-androsterone and iso-etiocholanolone. As the amount of the two latter compounds is very small, most of the ZIMMERMANN chromogen of this fraction consists of dehydroepiandrosterone (or its rearranged $i$-androstanolone).

Fraction III: Gradient column chromatography of androsterone and etiocholanolone together with results from 
TLC have shown that this fraction includes these two 17-KS. As 11-hydroxylated steroids to some extent have been transformed during hydrolysis into $\left.\Delta^{9}{ }^{11}\right)$-dehydroandrosterone and $\left.\Delta^{9}{ }^{11}\right)$-dehydro-etiocholanolone, which could not be separated from the corresponding saturated steroids, the values for androsterone and etiocholanolone are probably slightly high.

Fraction IV: The four 11-oxygenated derivatives of androsterone and etiocholanolone were recovered after gradient column chromatography. Qualitative studies of pooled eluates of this fraction have permitted the detection - by means of multiple two dimensional thin layer chromatography (Fig. 3) - of all these four steroids.

\section{Fractionation of $17-\mathrm{KS}$ from normal urines}

Table 1 summarizes the results obtained for the four eluate fractions after gradient elution chromatography of 15 normal urines ( 7 men and 8 women), in $\mathrm{mg} / 24 \mathrm{hrs}$. and in $\%$ of total $17-\mathrm{KS}$. In the table 1 are also given the results obtained by further separation of the steroids of fraction III by means of one-dimensional multiple thin-layer chromatography on silica gel, together with the ratios etiocholanolone/androsterone and 11-deoxy-/11-oxygenated steroids. Of the four fractions obtained after column chromatography the fraction containing the 11-oxygenated steroids (fraction IV) was submitted to one-dimensional, multiple chromatography using the system ethylacetate/cyclohexane $(60: 40)$; the results are given in table 2. - In two cases, equal aliquots of the urine were submitted to acid and enzymatic hydrolysis respectively. The results obtained for the different fractions with the two hydrolysis procedures have been summarized in table 3. - In 4 cases, the ratio etiocholanolone: androsteron was determined after treatment of equal aliquots of fraction III with osmium oxide and

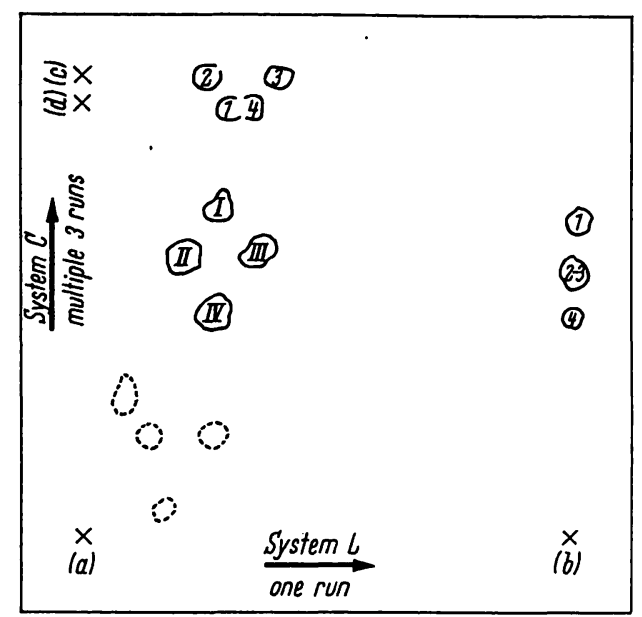

Fig. 3

Characterization of the steroids of fraction IV by means of a combination of two-dimensional and multiple thin-layer chromatography on silica gel G

First, the eluate of fraction IV obtained from the gradient-eluation chromatography, is deposited to the left (a) on the starting line of the plate and a mixture of the four standards to the right (b). The chromatoplate is submitted to 3 runs, using solvent system $C$ (ethylacetate cyclohexane 50:50). Thereafter mixtures of standards are deposited on a second starting line perpendicular to the first $(a-b)$ line: $11 \beta$-hydroxyetiocholanolone and 11 -ketoandrosterone in point (c) and $11 \beta$-hydroxyandrosterone and 11-keto-etiocholanolone in point (d). The chromatoplate is submitted to a fourth run, now in a second direction and with annther solvent system, $\mathrm{L}$, (chloroform/methanol, 19:1). The chromatoplate is stained with the anisaldehyde/sulphuric acid reaction

Steroid standards (Arabic numbers) and separated urinary steroids (Roman numbers) are shown as follows:

$11 \beta$-hydroxyandrosterone (1.II)

$11 \beta$-hydroxyetiocholanolone (2.II)

11 -ketoandrosterone $(3, \mathrm{III})$

11-keto-etiocholanolone $(4$, IV $)$

sodium permanganate in alkaline solution, respectively. The results obtained with these two treatments and those obtained with the general methods described here, are compared in table 4.

Tab. 1

Total 17-KS-excretion in normal individuals and the results of column and thin layer chromatographic separation. Individual values, mean values $\pm S D$ range $(A \pm S D)$ are given

\begin{tabular}{|c|c|c|c|c|c|c|c|c|c|c|c|c|c|c|c|}
\hline \multirow{2}{*}{$\begin{array}{c}\text { Men } \\
\text { Age }\end{array}$} & \multirow{2}{*}{$\begin{array}{c}\text { Total } \\
17 \mathrm{KS} ! \\
\mathrm{mg} / 24 \mathrm{hrs} .\end{array}$} & \multicolumn{2}{|l|}{ I } & \multicolumn{4}{|c|}{ Fractions } & \multicolumn{2}{|c|}{ IV } & \multicolumn{2}{|c|}{$\begin{array}{l}\text { Andro- } \\
\text { sterone }\end{array}$} & \multicolumn{2}{|c|}{$\begin{array}{l}\text { Etiocho- } \\
\text { lanolone }\end{array}$} & \multirow[b]{2}{*}{ E/A } & \multirow{2}{*}{$\begin{array}{c}\text { 11-desoxy } \\
11 \text {-oxy }\end{array}$} \\
\hline & & $\mathrm{mg}$ & $\%$ & $\mathrm{mg}$ & $\%$ & $\mathrm{mg}$ & $\%$ & $\mathrm{mg}$ & $\%$ & $\%$ & $\mathrm{mg}$ & & mg & & \\
\hline $\begin{array}{l}23 \\
29 \\
37 \\
37 \\
42 \\
67 \\
79\end{array}$ & $\begin{array}{l}6.10 \\
8.60 \\
6.50 \\
5.90 \\
6.10 \\
3.00 \\
4.80\end{array}$ & $\begin{array}{l}1.672 \\
0.645 \\
0.364 \\
0.496 \\
0.409 \\
0.270 \\
0.470\end{array}$ & $\begin{array}{r}27.4 \\
7.5 \\
5.6 \\
8.4 \\
6.7 \\
9.0 \\
9.8\end{array}$ & $\begin{array}{l}0.598 \\
0.576 \\
0.475 \\
0.507 \\
1.305 \\
0.252 \\
0.494\end{array}$ & $\begin{array}{r}9.8 \\
6.7 \\
7.3 \\
8.6 \\
21.4 \\
8.4 \\
10.3\end{array}$ & $\begin{array}{l}3.404 \\
6.846 \\
4.615 \\
4.095 \\
3.794 \\
2.208 \\
\mathbf{3} .029\end{array}$ & $\begin{array}{l}55.8 \\
79.6 \\
71.0 \\
69.4 \\
62.2 \\
73.6 \\
63.1\end{array}$ & $\begin{array}{l}0.427 \\
0.533 \\
1.047 \\
0.808 \\
0.592 \\
0.270 \\
0.806\end{array}$ & $\begin{array}{r}7.0 \\
6.2 \\
16.1 \\
13.7 \\
9.7 \\
9.0 \\
16.8\end{array}$ & $\begin{array}{l}34.7 \\
33.6 \\
34.0 \\
43.4 \\
19.4 \\
30.4 \\
25.3\end{array}$ & $\begin{array}{l}2.114 \\
2.821 \\
2.210 \\
2.561 \\
1.183 \\
0.913 \\
1.214\end{array}$ & $\begin{array}{l}21.1 \\
43.0 \\
37.0 \\
26.0 \\
42.7 \\
43.2 \\
37.8\end{array}$ & $\begin{array}{l}1.290 \\
4.025 \\
2.405 \\
1.534 \\
2.605 \\
1.295 \\
1.814\end{array}$ & $\begin{array}{l}0.61 \\
1.43 \\
1.09 \\
0.60 \\
2.20 \\
1.42 \\
1.49\end{array}$ & $\begin{array}{r}9.37 \\
13.92 \\
4.86 \\
5.70 \\
8.61 \\
8.11 \\
4.37\end{array}$ \\
\hline$A \% S D$ & $5.80 \pm 0.16$ & \multicolumn{2}{|c|}{$0.573 \pm 0.461$} & \multicolumn{2}{|c|}{$0.674 \pm 0.368$} & \multicolumn{2}{|c|}{$3.872 \pm 0.141$} & \multicolumn{2}{|c|}{$0.707 \pm 0.308$} & \multicolumn{2}{|c|}{$1.812 \pm 0.707$} & \multicolumn{2}{|c|}{$2.059 \pm 0.934$} & $1.23 \pm 0.53$ & $7.44 \pm 3.46$ \\
\hline $\mathbf{s}_{\mathbf{x}}$ & 0.06 & \multicolumn{2}{|c|}{0.163} & \multicolumn{2}{|c|}{0.130} & \multicolumn{2}{|c|}{0.050} & \multicolumn{2}{|c|}{0.109} & \multicolumn{2}{|c|}{0.251} & \multicolumn{2}{|c|}{0.331} & 0.19 & 1.23 \\
\hline Range & $3.00-8.60$ & \multicolumn{2}{|c|}{$0.26-1.67$} & \multicolumn{2}{|c|}{$0.25-1.31$} & \multicolumn{2}{|c|}{$2.21-6.85$} & \multicolumn{2}{|c|}{$0.27-1.17$} & \multicolumn{2}{|c|}{$0.91-2.82$} & \multicolumn{2}{|c|}{$1.29-4.03$} & $0.60-1.49$ & $3.56-13.92$ \\
\hline \multicolumn{16}{|l|}{$\begin{array}{l}\text { Women } \\
\text { Age }\end{array}$} \\
\hline $\begin{array}{l}15 \\
23 \\
23 \\
26 \\
40 \\
52 \\
60 \\
61\end{array}$ & $\begin{array}{l}1.80 \\
8.80 \\
8.50 \\
3.70 \\
5.10 \\
3.00 \\
9.10 \\
2.60\end{array}$ & $\begin{array}{l}0.140 \\
0.774 \\
1.284 \\
0.388 \\
0.507 \\
0.225 \\
0.427 \\
0.179\end{array}$ & $\begin{array}{r}7.8 \\
8.8 \\
15.1 \\
10.5 \\
9.9 \\
7.5 \\
4.7 \\
6.9\end{array}$ & $\begin{array}{l}0.137 \\
2.534 \\
0.782 \\
0.185 \\
0.298 \\
0.369 \\
1.156 \\
0.309\end{array}$ & $\begin{array}{r}7.6 \\
28.8 \\
9.2 \\
5.0 \\
5.9 \\
12.3 \\
12.7 \\
11.9\end{array}$ & $\begin{array}{l}1.303 \\
4.891 \\
5.134 \\
2.597 \\
3.864 \\
2.022 \\
5.615 \\
1.518\end{array}$ & $\begin{array}{l}72.4 \\
49.9 \\
60.4 \\
70.2 \\
75.8 \\
67.4 \\
61.7 \\
58.4\end{array}$ & $\begin{array}{l}0.220 \\
1.100 \\
1.292 \\
0.529 \\
0.431 \\
0.384 \\
1.902 \\
0.590\end{array}$ & $\begin{array}{r}12.2 \\
12.5 \\
15.2 \\
14.3 \\
8.4 \\
12.8 \\
20.9 \\
22.7\end{array}$ & $\begin{array}{l}28.7 \\
26.2 \\
27.6 \\
33.1 \\
42.7 \\
31.0 \\
20.9 \\
25.5\end{array}$ & $\begin{array}{l}0.517 \\
2.305 \\
2.346 \\
1.225 \\
2.179 \\
0.930 \\
1.898 \\
0.663\end{array}$ & $\begin{array}{l}43.7 \\
23.7 \\
32.8 \\
37.1 \\
33.1 \\
36.4 \\
40.5 \\
32.9\end{array}$ & $\begin{array}{l}0.786 \\
2.086 \\
2.788 \\
1.373 \\
1.686 \\
1.092 \\
3.716 \\
0.855\end{array}$ & $\begin{array}{l}1.52 \\
0.91 \\
1.19 \\
1.12 \\
0.77 \\
1.17 \\
1.94 \\
1.29\end{array}$ & $\begin{array}{l}6.55 \\
6.75 \\
4.58 \\
5.26 \\
9.66 \\
6.23 \\
3.56 \\
3.10\end{array}$ \\
\hline$A \pm S D$ & $5.30 \pm 0.32$ & \multicolumn{2}{|c|}{$0.491 \pm 0.381$} & \multicolumn{2}{|c|}{$0.721 \pm 0.773$} & \multicolumn{2}{|c|}{$3.368 \pm 1.725$} & \multicolumn{2}{|c|}{$0.806 \pm 0.574$} & \multicolumn{2}{|c|}{$1.508 \pm 0.761$} & \multicolumn{2}{|c|}{$1.798 \pm 1.024$} & $1.24 \pm 0.36$ & $5.71 \pm 2.09$ \\
\hline $\mathbf{s}_{\mathbf{x}}$ & 0.11 & \multicolumn{2}{|c|}{0.135} & \multicolumn{2}{|c|}{0.274} & 0.6 & & 0.2 & & & 270 & & 363 & 0.13 & 0.74 \\
\hline Range & $1.89-9.10$ & 0.14 & -1.28 & 0.14 & -2.53 & 1.30 & -5.62 & 0.22 & -1.90 & 0.52 & -2.35 & 0.79 & -3.72 & $0.77-1.94$ & $3.10-9.66$ \\
\hline
\end{tabular}


Tab, 2

Results of thin-layer chromatographic separation of fraction IV, obtained after column chromatography. Individual values, mean values \pm SD $(A \pm S D), S E M$ and range are given

\begin{tabular}{|c|c|c|c|c|c|c|c|c|c|c|}
\hline \multirow{2}{*}{$\begin{array}{l}\text { Men } \\
\text { Age }\end{array}$} & \multirow{2}{*}{$\begin{array}{c}\text { 11-oxygenated } \\
17-\mathrm{KS} \\
\mathrm{mg} / 24 \mathrm{hrs} .\end{array}$} & \multirow{2}{*}{\multicolumn{3}{|c|}{ 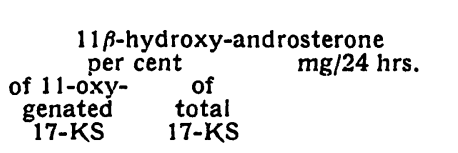 }} & \multicolumn{3}{|c|}{$\begin{array}{l}\text { 11 } \beta \text {-hydroxy-etiocholanolone } \\
\text { and 11-0xo-androsterone }\end{array}$} & \multicolumn{3}{|c|}{$\begin{array}{l}\text { 11-oxo-etiocholanolone } \\
\text { per cent } \mathrm{mg} / 24 \mathrm{hrs} \text {. }\end{array}$} \\
\hline & & & & & $\begin{array}{l}\text { of 11-oxy- } \\
\text { genated } \\
17-\mathrm{KS}\end{array}$ & $\begin{array}{c}\text { of } \\
\text { total } \\
17-\mathrm{KS}\end{array}$ & & $\begin{array}{l}\text { per c } \\
\text { of 11-oxy- } \\
\text { genated } \\
17-\mathrm{KS}\end{array}$ & $\begin{array}{l}\text { of } \\
\text { total } \\
17-K S\end{array}$ & mg/24 hrs. \\
\hline $\begin{array}{l}23 \\
29 \\
37 \\
37 \\
42 \\
48 \\
67\end{array}$ & $\begin{array}{l}0.43 \\
0.15 \\
0.81 \\
1.05 \\
0.59 \\
1.17 \\
0.27\end{array}$ & $\begin{array}{r}26.1 \\
30.3 \\
37.0 \\
31.6 \\
4.8 \\
18.0 \\
37.4\end{array}$ & $\begin{array}{l}1.8 \\
1.9 \\
5.0 \\
5.1 \\
0.5 \\
3.8 \\
3.4\end{array}$ & $\begin{array}{l}0.110 \\
0.161 \\
0.295 \\
0.332 \\
0.030 \\
0.210 \\
0.112\end{array}$ & $\begin{array}{l}45.9 \\
27.7 \\
27.1 \\
46.6 \\
36.2 \\
48.5 \\
18.1\end{array}$ & $\begin{array}{r}3.2 \\
1.7 \\
3.7 \\
7.5 \\
3.5 \\
10.1 \\
1.6\end{array}$ & $\begin{array}{l}0.195 \\
0.147 \\
0.218 \\
0.439 \\
0.214 \\
0.567 \\
0.054\end{array}$ & $\begin{array}{l}27.9 \\
41.9 \\
36.9 \\
21.8 \\
59.0 \\
33.5 \\
44.5\end{array}$ & $\begin{array}{l}2.0 \\
2.3 \\
5.0 \\
3.5 \\
5.7 \\
7.0 \\
4.0\end{array}$ & $\begin{array}{l}0.122 \\
0.222 \\
0.295 \\
0.229 \\
0.348 \\
0.391 \\
0.314\end{array}$ \\
\hline $\begin{array}{l}A \pm S D \\
S_{X} \\
\text { Range }\end{array}$ & $\begin{array}{c}0.69 \pm 0.33 \\
0.12 \\
0.27-1.17\end{array}$ & & & $\begin{array}{c}0.179 \neq 0.108 \\
0.041 \\
0.03-0.35\end{array}$ & & & $\begin{array}{c}0.269 \pm 0.187 \\
0.071 \\
0.05-0.57\end{array}$ & & & $\begin{array}{c}0.249 \pm 0.102 \\
0.039 \\
0.12-0.39\end{array}$ \\
\hline \multicolumn{11}{|l|}{$\begin{array}{l}\text { Women } \\
\text { Age }\end{array}$} \\
\hline $\begin{array}{l}15 \\
23 \\
23 \\
26 \\
40 \\
52 \\
60 \\
61\end{array}$ & $\begin{array}{l}0.22 \\
1.10 \\
1.29 \\
0.53 \\
0.43 \\
0.38 \\
1.90 \\
0.59\end{array}$ & $\begin{array}{l}13.1 \\
10.0 \\
12.6 \\
18.6 \\
36.5 \\
18.9 \\
11.3 \\
10.6\end{array}$ & $\begin{array}{l}1.6 \\
1.2 \\
1.9 \\
2.7 \\
3.5 \\
2.4 \\
2.4 \\
2.4\end{array}$ & $\begin{array}{l}0.030 \\
0.110 \\
0.163 \\
0.079 \\
0.157 \\
0.072 \\
0.218 \\
0.062\end{array}$ & $\begin{array}{l}26.1 \\
33.0 \\
28.9 \\
26.7 \\
15.8 \\
39.0 \\
51.8 \\
47.2\end{array}$ & \begin{tabular}{r|}
3.2 \\
4.2 \\
4.5 \\
3.8 \\
1.9 \\
5.0 \\
10.8 \\
10.7
\end{tabular} & $\begin{array}{l}0.057 \\
0.363 \\
0.373 \\
0.141 \\
0.068 \\
0.150 \\
0.983 \\
0.278\end{array}$ & $\begin{array}{l}60.8 \\
57.0 \\
58.5 \\
54.7 \\
47.6 \\
42.1 \\
36.9 \\
42.2\end{array}$ & $\begin{array}{l}7.2 \\
7.1 \\
8.8 \\
7.8 \\
4.0 \\
5.4 \\
7.7 \\
9.6\end{array}$ & $\begin{array}{l}0.134 \\
0.627 \\
0.756 \\
0.287 \\
0.205 \\
0.162 \\
0.701 \\
0.250\end{array}$ \\
\hline $\begin{array}{l}A \pm S D \\
S_{x}\end{array}$ & $\begin{array}{l}0.81 \pm 0.57 \\
0.20\end{array}$ & & & $\begin{array}{c}0.111 \pm 0.063 \\
0.022\end{array}$ & & & $\begin{array}{l}0.302 \pm 0.302 \\
0.107\end{array}$ & & & $\begin{array}{c}0.390 \pm 0.259 \\
0.092\end{array}$ \\
\hline Range & $0.22-1.90$ & & & $0.03-0.22$ & & & $0.06-0.98$ & & & $0.13-0.76$ \\
\hline
\end{tabular}

Tab. 3 Comparison of the values obtained for the fractionation of $17-\mathrm{KS}$ and the ratio E/A after acid and enzymatic hydrolysis respectively, of urines
from two normal men

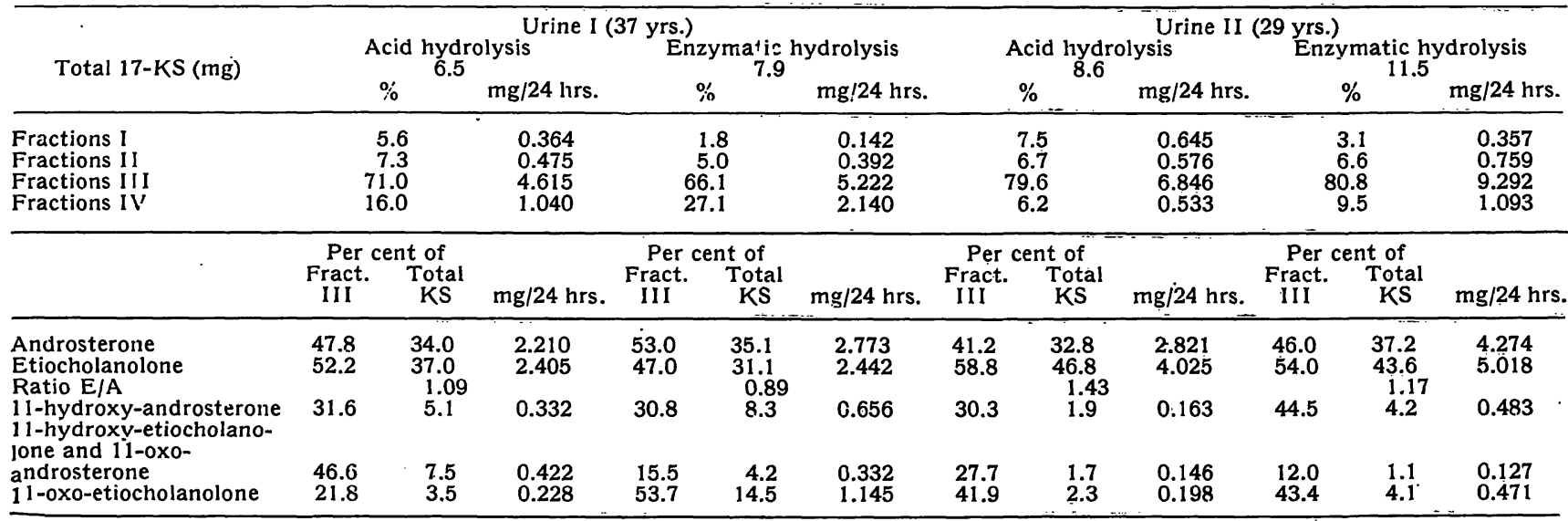

Tab. 4

Ratio Etiocholanolone/androsterone obtained after (a) treatment with osmium-VI-tetraoxide

b) sodium permanganate/potassium hydroxide-treatment (c) TLC of fraction III without further treatment

\begin{tabular}{cccc}
\hline Age & \multicolumn{3}{c}{ Ratio Etiocholanolone/Androsterone } \\
& (a) & (b) & (c) \\
\hline 23 & 1.12 & 1.17 & 0.91 \\
23 & 0.85 & 0.95 & 1.19 \\
23 & 1.01 & 0.65 & 0.61 \\
40 & 1.40 & 0.90 & 0.77 \\
& $(1.09)$ & $(0.92)$ & $(0.87)$
\end{tabular}

\section{Discussion}

Hydrolysis

The optimal method for the study of the urinary $17-\mathrm{KS}$ is the separation of the different conjugates of each steroid and their determination. However, such a method involves a series of separation procedures which makes it applicable only for studies of isolated cases. For routine purposes it is necessary to develop methods which permit the analysis of a large number of samples, and a comparison between values obtained in different laboratories. The most common hydrolysis procedure is still that using strong acids such as hydrochloric or sulphuric acid. It is generally accepted that enzymatic hydrolysis is the best way of avoiding destruction of the urinary 17-KS and the formation of artefacts. However, the use of enzyme preparations is costly and the hydrolysis is slow; besides, some sulphates - such as those with $5 \alpha / 3 \alpha$, $5 \beta / 3 \alpha$ and $5 \beta / 3 \beta$-structures (22) are not hydrolysed at all or only to a very small degree by sulphatase preparations of Helix Pomatia or Patella vulgata and therefore require an additional solvolysis for their liberation. 'Furthermore, the presence in the urine of non-competetive or competitive inhibitors, e. g. sulphates, phosphates, chlorides and glucuronides of administered drugs makes a pre-treatment of the urines necessary or an extraction of the conjugates before hydrolysis (23). The presence of artefacts after hydrolysis with bacterial $\beta$-glucuronidase has been demonstrated by VestergaARD (24). After 
incubation of DHA-sulphate with this enzyme preparation, he could identify i-androstanolone by means of infraredspectroscopy, together with a second less important artefact. The re-investigation of the artefacts formed by hydrochloric acid hydrolysis, using gaschromatographic techniques (25) and the influence of both hydrochloric and sulphuric acid procedures on the gradient elution chromatography of 17-KS (26) showed that of the two procedures, sulphuric acid hydrolysis caused less destruction and transformation of the diffe1ent urinary 17-KS. By means of gas-chromatographic techniques. CREECH and ABBotr (27) could not find artefacts after employing sulphuric acid hydrolysis with simultaneous extraction. Simultaneous extraction has however not been employed in the present investigation. This was due to the fact that urine colletions and steroid extractions in some pathological cases $(27$ A) were started several years ago, and that we wanted to have comparable results all through the study.

\section{Fractionation}

The results shown in table 1 for dehydroepiandrosterone, androsterone and etiocholanolone are in agreement with those which have been obtained by others $(28-31)$ by using different fractionation methods and hydrolysis procedures. - The values for the ratio etiocholanolone/ androsterone are identical with those given by other authors $(29,32,33)$ and are the same in both sexes. For the ratio betwreen the 11-deoxy-17-ketosteroids (androsterone, etiocholanolone and DHA) and the 11-oxygenated $17-\mathrm{KS}$ we found values slightly higher than those given by Dingenranse et al. (1) using hydrochloric acid hydrolysis and column adsorption chromatography, or those given by KAPPAS and GALLAGHER (31) obtained by means of column and paper chromatography after $\beta$-glucuronidase and solvolysis. They are, however, much higher than those described by BrooksBANK and Salokangas (34) and VestergaARd (21) obtained after acid hydrolysis with simultaneous extraction. This difference could be explained by the fact that these authors have corrected their results for the different chromogenicity of the analyzed steroids, and that by the use of acid hydrolysis with continous extraction the transformation of 11-oxygenated steroids is decreased.

Our results show that the ratio between 11-desoxy- and 11-oxy-17-KS decreases with age, as has been shown by BROOKSBANK and Salokangas (34). - A comparison between the two hydrolysis procedures used in this investigation shows that the values obtained for total 17-KS, as well as for the steroids of the fractions III and IV are higher if enzymatic hydrolysis is used. The opposite has been found, as might be expected, in elutionfraction I, depending upon the higher formation of artefacts when acid hydrolysis is used. The ratio etiocholanolone/androsterone is smaller after enzymatic hydrolysis, but the difference is not significant.

The figures in table 3 also show that the differences between acid and enzymatic hydrolysis are most marked for the steroids in fraction IV. This means that when the main interest is focused upon the steroids in fraction IV, enzymatic hydrolysis should be carried out. - In order to determine to which degree the conversion of 11hydroxylated steroids to $\Delta^{9}\left(^{11}\right)$ dehydroandrosterone and $\Delta^{9}\left({ }^{11}\right)$-dehydroetiocholanolone could affect the calculation of the ratio etiocholanolone/androsterone, this ratio has been determined also after hydroxylation of two $\Delta^{9}{ }^{(11)}$ unsaturated steroids. The results of table 4 show that no great differences were obtained in normal individuals when this ratio was calculated with or without the oxidation treatment. However, as we were unable to obtain the $\Delta^{9}\left({ }^{11}\right)$-unsaturated compounds as standards, it was impossible to investigate whether the hydroxylation of the double bonds at $\Delta^{9}{ }^{(11)}$ by the two oxidation procedures was complete.

Ackenowiledgments: Supported by grant to L. E. Börtiger from the Swedish Medical Research Council. B. P. LisBon thanks Schering AG, Berlin, for a personal grant in reproductive endocrinology. We want to thank Professor W. KLYNE, London, for test samples of $11 \beta$-hydroxyandrosterone, $11 \beta$-hydroxyetiocholanolone, 11-oxoandrosterone and 11-oxo-etiocholanolone.

\section{References}

1. Dingemanse, E., L. G. Huis Iv't Veld and S. L. HartonghKatz, J. Clin. Endocrin. 12, 66 (1952). - 2. Lisboa, B. P., J. Chromatogr. 13, 391 (1964). - 3. LisBoA, B. P., J. Pharm. Bełgique 1965, 435. - 4. FeHÉr, T., Mikrochimica Acta 1965, 105. - 5. Plantin, L. O. and G. Birke, Acta med. scand. suppl. 291, 1954. - 6. Pincus, G. and W. H. Pearlman, Endocrinology 29, 413 (1941). - 7. Hamburger, C., Acta endocr., K’hvn 9, 129 (1952). - 8. Allen, W. H., S. J. Hayvard and A. Pinto, J. Clin. Endocrin. 10, 54 (1950). - 9. GrBson, J. G. and W. A. Evans, J. Clin. Invest. 16, 301 (1937). - 10. ZxGMuntowicz, A.S., M. Wood, E. Chrsto and N. B. Tatrot, J. Clin. Endocrinology 11, 578 (1951). - 11. Lebreton, P., Bull Soc. Chim. France 1960, 2188. - 12. LisboA, B. P., Steroids 6, 506 (1965). - 13. LisBOA, B. P., Steroids 7, 41 (1966). - 14. LisBOA, B. P., Systemic analysis of Steroids. Thesis, Karolinska institutet, Stockholm 1965. - 15. Lisbon, B. P. and E. Diczfalusy, Acta endocr., K'hrn 43, 545 (1963). - 16. KLOPper, A. I., E. R. MrCFIrE and
J. B. Brown, J. Endocr. 12, 209 (1955). - 17. Zderic, J. A., H. Carpio and C. Djerassi, J. Org. Chem. 24, 909 (1959). 18. Savary, P. and P. Desnuelle, Soc. Chem., France 20, 939 (1953). - 19. Vestergaard, P., I. Chromatogr. 3, 560 (1950). 20. Wirior, G., Recherches sur l'emploi du fractionnement chromatographique avec gradient de polarité pour l'etude de l'elimation des 17 -ceto-stéroides urinaires. $\mathrm{R}$. Foulon $3 \mathrm{Cie}, \mathrm{Pa}$ is (1963). - 21. Vestergaard, P., Acta endocr., K'hrn suppl. 67, 3 (1962). - 22. Jarrige, P., J. Yon and M. F. Jayle, Bull Soc. Chim. biol. 45, 783 (1963). - 23. Henry, R., Annals Biol. Clin. 23, 211 (1965). - 24. VestergaArd, P., Acta Endoctin. (Kbh), suppl. 64, 50 (1962). - 25. Cawley, L. P., B. O. Musser, W'. FACCette, S. Beckloff and H. Learned, Clin. Chem. 11, 1009 (1965). - 27 A. Bötriger, L. E. and LisBoA, B. P., Clin. chim. Acta 16, 109 (1967). - 26. Vestergaard, P. and B. Claussen, Acta ẹdocr., K'hvn suppl. 64, 35 (1962). - 27. CReECH, B. G. and J. P. Aввотr, Amer. J. Clin. Path. 42, 514 (1964). — 28' JaMes, V. 
H. T., J. Endocrin. 22, 195 (1961). - 29. Makesh, V. B., R. B. Greenblatt, C. K. Aydar, S. Roy, R. A. Puebla and J. O. Ellegood, J. Clin. Endocrin. 24, 1283 (1964). - 30. Haiman, B. L. and M. M. Martin, J. Clin. Endocrin. 24, 1195 (1964). 31. Kappas, A. and T. F. Gallagher, J. Clin. Invest. 34, 1566
(1955). - 32. Beas, F., R. P. Zurbrugg, J. Cara and I. I. Gardner, J. Clin. Endocrin. 22, 1090 (1962). - 33. Starnes, W. R., T. F. PartLow, M. C. Grammer, L. Kornel and S. R. Hrll, Analy. Biochem. 6, 82 (1963). - 34. Brooksbank, B. W. L. and A. Salokangas, Acta endrocr., K'hvn 30, 231 (1959).

\author{
Doz. Dr. L. E. Böttiger \\ King Gustaf Vth Research Institute \\ Stockholm, Schweden
}

Dr. B. T. Lisboa

Karolinska Sjukhuset

Stockholm 60/Schweden

\title{
Die Problematik der GoRdonschen Testsubstanz
}

\author{
Von H.-J. Lieschke, H. Hartmann, J. Löbe, H. Кoch und K. Seige
}

Auls der Medizinischen Universitätsklinik Leipzig (Direktor:Prof. Dr. R. Em mirich), der Radiologischen Universitätsklinik Leipzig (Direktor: Prof. Dr. W. Oelßner) und dem Institut für angewandte Radioaktivität (elem. Direktor: Prof. Dr. C. F. Weiss) der Deutschen Akademie der Wissenscbaften zu Berlin

(Eingegangen am 26. September 1966)

Es wird auf die Instabilität der GoRDon'schen Testverbindung (,PVP-T_131 J“) zum Nachweis der Exsudativen Enteropathie hingewiesen und über die Ergebnisse von Stuhl- und Urindialysen berichtet.

Danach besteht die Aktivität des Urins zu 90\% aus abgespaltenem ionogenen ${ }^{131}$ Jod, die fäkkale Aktivität zu mindestens 30-50\% aus freiem ionogenen ${ }^{131} \mathrm{Jod}$. Als Modellsubstanz für den enteralen Eiweißverlust ist die Substanz daher nicht geeignet. - Die Ursache der erhöhten Abspalterate in vivo sowie der Alterung des Präparates in vitro dürfte in der einfachen Anlagerung des ${ }^{131}$ Jods an PVP-Doppelbindungen zu suchen sein. Die von Gordon angenommene aromatische Bindung des ${ }^{131}$ Jod am PVP-T wird abgelehnt.

The instability of Gordon's test compound, "PVP-T_131I", for the diagnosis of exudative enteropathy was studied, and results from the dialysis of faeces and urine are reported.

Free, ionisable ${ }^{131}$ i is responsible for up to $90 \%$ of the activity of the urine and at least $30-50 \%$ of the faeces. Thus the compound cannot be used for the measurement of the enteric loss of protein. - The increased rate of cleavage in vivo and the ageing of the preparation in vitro is caused by the simple transfer of ${ }^{131} \mathrm{I}$ to the unsaturated bonds of PVP. Gordon was therefore wrong in assuming that ${ }^{131} \mathrm{I}$ is bound by an aromatic linkage in PVP-T.

Die Verwendung von jodmarkiertem, toluidinhaltigem Polyvinylpyrrolidon ("PVP-T-131 J“) beim GoRDONTest $(1,2)$ zum Nachweis der Exsudativen Enteropatbie (3-7) stellt gewisse Stabilitätsanforderungen an dieses Präparat, um überhaupt annähernde Aussagen über einen enteralen Verlust treffen zu können. Diesen Stabilitätsanforderungen hält das Präparat nicht stand. Die Aussagekraft des Gordon-Testes mindern zwei nicht abzuschätzende Fehlermöglichkeiten; nämlich die erwähnte Instabilität des PVP-T-131 J in vivo und die problematische Korrelation zwischen enteralem Verlust der Testsubstanz und enteralem Proteinverlust (8).

Der Einball von ${ }^{131}$-Jod in das PVP: Aromatischer Einbau oder Additionsreaktion?

Die Abhängigkeit der ${ }^{131}$-Jodeinbaurate in das PVP von der Markierungsart ist erwiesen $(9,10)$. VoN GunTEN (9) und Medenwald (10) konnten durch UV-Bestrahlung einen höheren ${ }^{131}$-Jodeinbau in das PVP-T bzw. in das PVP-Molekül nachweisen, als mit der klassischen GoRDoN'schen Markierungsmethodik möglich ist. Die erste Beobachtung des höheren Aktivitätseinbaues unter UV-Bestrahlung geht dabei auf GorDON zurück. Das GoRDON'sche Markierungsverfahren basiert auf der - Úberlegung, daß unter Anwesenheit von p-Toluidin polymerisiertes PVP noch freie Aminogruppen enthalten müßte. Diese sollen sich mit Natriumnitrit in mineralsaurer Lösung diazotieren und sich ähnlich der Sandmeyer-Reaktion bei Bromiden und Chloriden gegen trägerfreies ${ }^{131}$ Jod austauschen lassen (11). GoRdoN (11) nahm daher folgende Formel für sein PVP-T-131 JProdukt an (Abb. 1).

Die Instabilität des Gordon'schen Markierungsproduktes läßt aber berechtigte Zweifel an der aromatischen Bindung des ${ }^{131} \mathrm{Jod}$ aufkommen. Offenbar kommt es
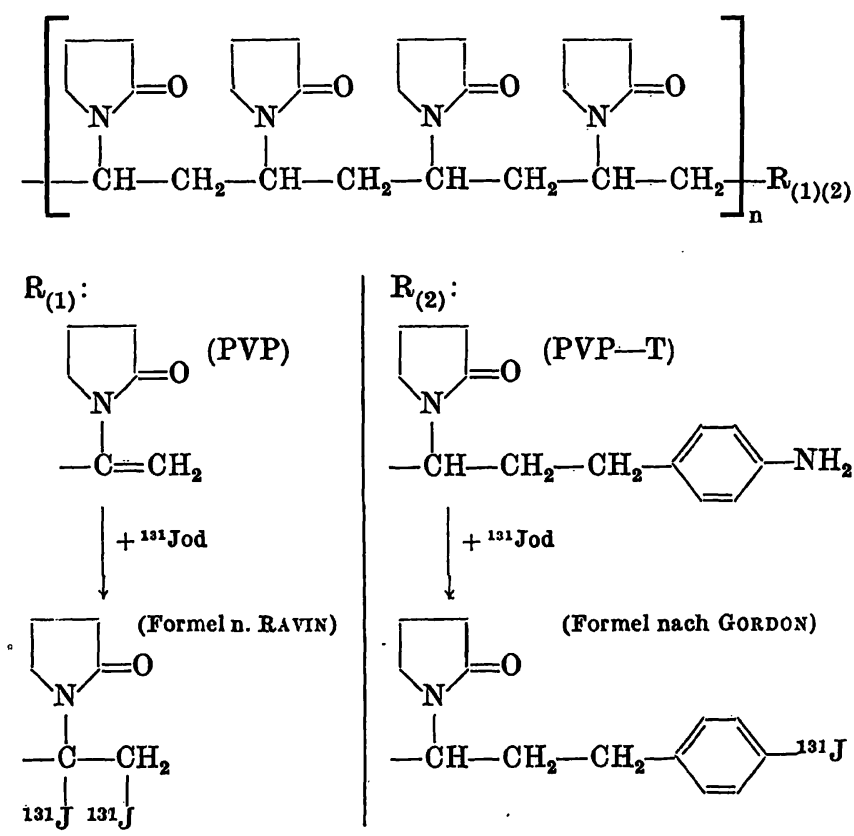

Abb. 1

Die hypothetische Formel für das PVP-T-131 J nach Gordon 